\title{
Sustainability of future coasts and estuaries: A synthesis
}

Article · December 2016

DOI: 10.1016/j.ecss.2016.11.017

CITATIONS

0

5 authors, including:

\section{Newton Alice}

Universidade do Algarve

101 PUBLICATIONS 1,820 CITATIONS

SEE PROFILE

Hua Zhang

Chinese Academy of Sciences

54 PUBLICATIONS 435 CITATIONS

SEE PROFILE

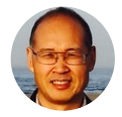

Zai-Jin You

Ludong University

71 PUBLICATIONS 366 CITATIONS

SEE PROFILE

Eric Wolanski

James Cook University

322 PUBLICATIONS 10,636 CITATIONS

SEE PROFILE

Some of the authors of this publication are also working on these related projects:

Project Estuarine hydrodynamics View project

BaltCoast - A Systems Approach Framework for Coastal Research and Management in the Baltic View 


\section{Sustainability of future coasts and estuaries: A synthesis}

Coasts are at the nexus of the Anthropocene, where land, marginal seas and atmosphere meet along a thin strip that is inhabited by nearly half the human population (Wolanski and Elliott, 2015). Coasts are often fringed by rich habitats such as mangroves, saltmarshes, inter-tidal mud and sand flats, seagrass meadows, kelp forests and coral reefs that provide a valuable range of ecosystem services to humans and to the adjacent marginal seas (Van den Belt and Costanza, 2011). It is the highly dynamic system that is constantly being reshaped by changing natural forces and anthropogenic activities. Coastal systems and human societies form coastal social-ecological systems that increasingly face multiple pressures, which threaten their ecological and economical sustainability. Common pressures include changes to land use and hydrology, land reclamation, coastal sand mining, harbour dredging, pollution and eutrophication, overexploitation such as overfishing, all in the context of climate change. During the 20th Century, coastal scientists studied the problems and issues arising along the coasts (Ramesh et al., 2015). Now, in the 21st Century, their focus must increasingly be about how to solve these problems and issues through better management and innovative approaches. To study these matters, two workshops were held in Yantai, P.R. China, in September 2015, hosted by the Yantai Institute of Coastal Zone Research, CAS. The outcome of these workshops is this special issue of Estuarine, Coastal and Shelf Science.

Our Special Issue has unprecedented international coverage, providing an extensive series of papers with an extraordinary variety of case studies worldwide (Fig. 1). These papers describe sustainability issues in Australia (Brodie and Pearson), Bangladesh (Nicholls et al.), China (Li et al.; Wu et al. - 2 papers), Guam (Shelton and Richmond), India (Benthou et al.), Japan (Matsuda and Kokubu), Pakistan (Kidwai et al.), Portugal (Sampath and Boski), USA (Day et al.; Kemp et al.), Vietnam (Nhan), West and East Africa (Diop and Scheren), Nigeria (Abgoola et al.) and about world-wide delta sustainability (Day et al.). All the estuaries, deltas and coastal waters in those study sites suffer environmental damage from a wide range of human activities that include changing land-use in the watershed, dams and irrigation projects and river diversion changing the hydrology and the sediment transport of rivers, changing uses and often over-development of the coast, land reclamation in the estuaries and tidal wetlands, dredging and pollution, coastal squeeze of the remaining coastal wetlands, overfishing, climate change, and others. However, the outcome for the ecosystem health varies from site to site, from doom and gloom stories to possibly hopeful stories and even some bright spots. These lessons to be extracted are thus what determine the commonalities and the differences between biophysical and socio- economic processes that determine the different ecosystem health at these sites, and their likely evolution in the foreseeable future.

The papers in this special issue all highlight the impact of multiple pressures, something that complicates management due to historical, political and legal reasons. The impacts of these pressures are often acting in cumulative and synergistic manners, and readily affecting the overall health and stability of the estuarine and coastal ecosystem, and threatening their resilience over the short- and long-term. This is exemplified in the paper by Diop and Scheren that highlights the enormous challenges now faced by the coastal states of Eastern and Western Africa to restore and manage their estuarine and coastal resources after decades of benign neglect when the multiple stressors were allowed to grow unchecked. A major overhaul of the governance and management of the coastal and marine environment at national to regional scales in East and West Africa is needed.

The importance of multiple stressors is also illustrated in the paper by Brodie and Pearson about the Great Barrier Reef (GBR) in Australia. While the GBR is a World Heritage site, many of the species and ecosystems of the GBR are in poor condition and continue to decline due to catchment pollutant runoff, the effects of fishing and climate change impacts (e.g. resulting in coral bleaching). The current management regime is clearly inadequate to prevent further decline. Brodie and Pearson propose a management largely based on 'triage' to strengthen management in the areas where ecosystems are still in good condition, as well as cross-boundary management to include terrestrial, freshwater and marine ecosystems. This requires two major commitments to bridge the sciencepolicy gap (Borja et al., 2016): (i) funding to effectively solve landbased pollution issues before climate change impacts fully on the GBR ecosystems; and, (ii) that Australia adopts greenhouse gas emissions control at a scale relevant to protecting the GBR.

The construction of dams and reservoirs since the 1950s has caused an average $44 \%$ decline in sediment supply to 33 of the world's major river deltas, and reductions in sediment loads coupled with rising sea level are affecting sustainability of deltaic ecosystems worldwide (Syvitski et al., 2009). Papers in this special issue quantify these effects for the estuaries of the Guadiana, Indus, Mississippi, Yellow and Changjiang rivers. The issue of multiple pressures that include dams is addressed in the paper of Sampath and Boski, on the morphological evolution of Guadiana estuary in Portugal during the 21st century. The effects of a dam-induced reduction in river discharge and projected sea-level rise has resulted in a net loss of sediment in the estuary. The results indicate that the legal requirement to maintain a minimum environmental flow are insufficient to maintain the ecosystem. Thus the European 


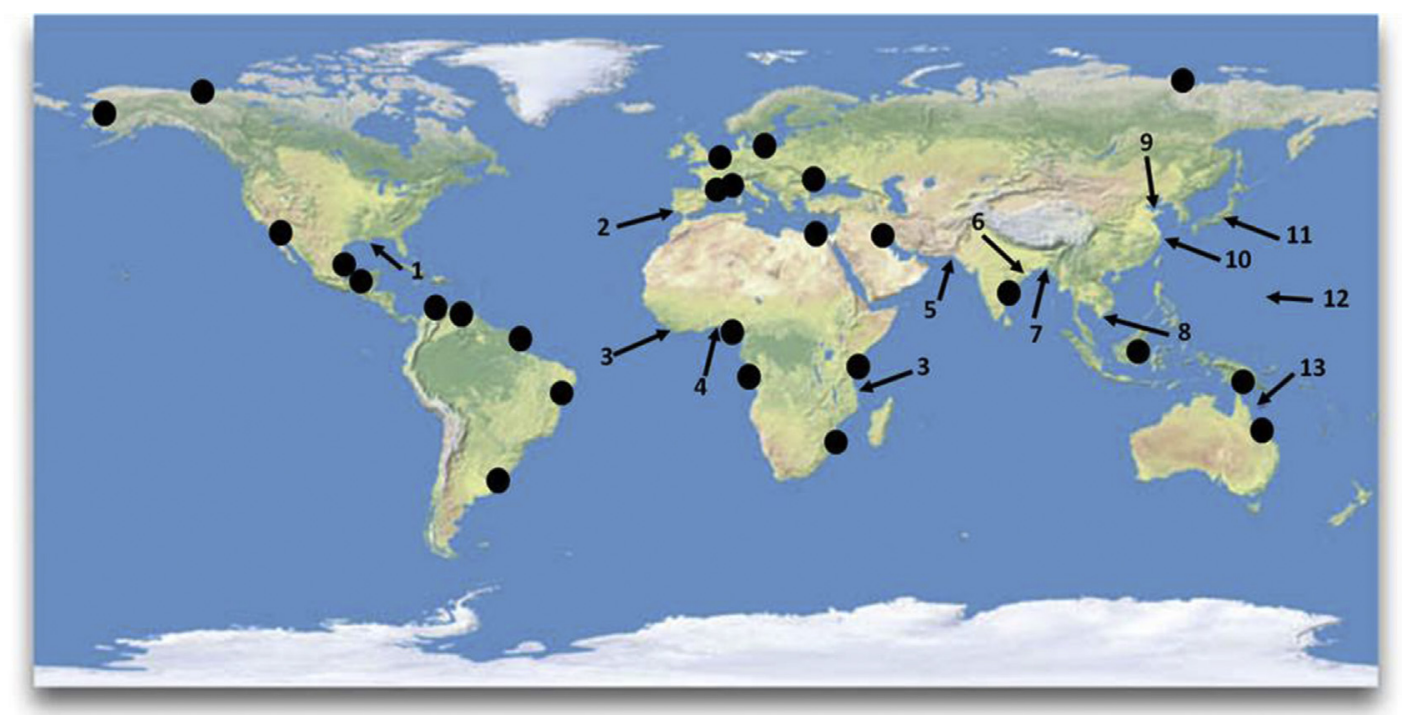

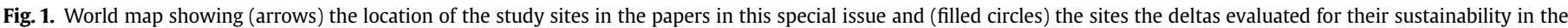

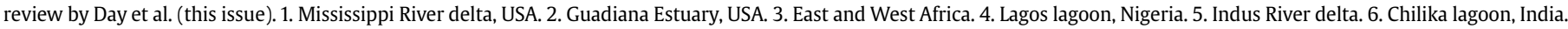

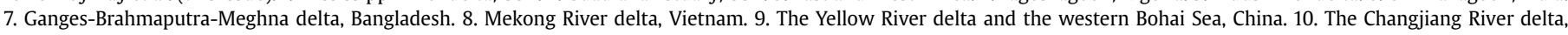

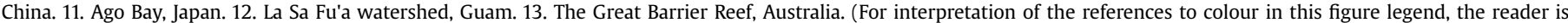
referred to the web version of this article.)

legislation needs to be updated to include the full spectrum of natural flows and their temporal variability in order to better cope with future sea-level rise.

Multiple human-induced stressors including dams are also impacting the Indus River delta in Pakistan as is described in the paper of Kidwai et al. These stressors are the severe decrease of freshwater flow in the Indus River as a result of extraction of water for irrigation, industrial and potable water. This is causing hypersalinity, destroying coastal wetlands on which the coastal fisheries depend, and impacting the direct exploitation of the delta ecosystems and its coastal fisheries by local delta communities and external users. Proposed remedial measures include the creation of Marine Protected Areas and ecosystem-based management of the Indus River delta resources.

The paper of Kemp et al. documents the rapid shrinking of deltaic wetland area in the Mississippi River delta (USA), which has lost nearly $5000 \mathrm{~km}^{2}$ to open water since 1932, much of the loss due to the human activities of building dams, flood control levees and dredging navigation and oil/gas/pipeline channels while strong, natural meteorological and oceanographic drivers continue to also impact the delta. The Yellow River freshwater discharge has been declining steadily since the 1950s, and is now almost entirely regulated. Man-made floods are generated in summer. These floods are a primary contributor of the terrestrial materials to the Bohai Sea in China, as discussed in the 1 st paper of Wu et al. The high concentrations of nutrients from these man-made floods play a significant role in sustaining phytoplankton growth in coastal waters of the western Bohai Sea off the Yellow River delta. In February to May, when the river flow is very low, strong winds and large waves re-suspend and vertically mix the nutrient-rich riverine sediment deposited after the man-made river floods in summer, resulting in higher chlorophyll-a concentrations. Even with such a large human impact in the Yellow River catchment, natural events occasionally remind us that we cannot forget nature either. Indeed, as discussed in the 2nd paper of Wu et al., the passage of typhoon Meari caused significant surface cooling and an abnormal increase in sea surface elevation along that same coast, and also resulted in an increase of $2-3{ }^{\circ} \mathrm{C}$ in temperature, a decrease of 0.3 in salinity and a two-fold increase of Chl-a concentration in the middle layer.

The Yellow River delta degradation story mirrors that of the Changjiang River delta, also in China. In their paper about the Changjiang River delta, $\mathrm{Li}$ et al. report that dams have cut off about $2 / 3$ of the sediment flux to the sea and $60 \%$ of the dissolved silicate load, while total phosphorous and total nitrogen transport to the delta are many times more than they were a few decades ago due to wastewater from urban and rural areas. They describe the details of the estuarine degradation since the 1950s, by using sedimentary biological silicate and total organic carbon as environmental proxies. The whole ecosystem has been degraded and it is unclear what management solutions maybe possible for remediation.

A somewhat similar story of historical degradation is also reported by Abgoola et al. for the wetlands of the Lagos lagoon, in Nigeria. Large-scale land reclamation, refuse and sewage dumping have had a substantial impact on the ecological health of these wetlands. Nevertheless Abgoola et al. find that the Lagos wetland ecosystems still have some semblance of natural habitat. Thus the destruction and unwise use of the resources must be prevented to avoid destroying what remains of these wetlands, even if they are degraded, if only because the livelihood of local communities and their lifestyle depend on these wetlands.

In view of such degradation, what are the solutions? Any solution must start from our willingness to define our future vision of the coast and our coastal aspirations. Day et al. in their paper on delta sustainably demonstrate that the impact of land-use and dams in the catchment, together with climate change and the cost of energy, will make achieving delta sustainability increasingly difficult the more we delay action to restore natural delta functioning through the use of an ecological engineering approach to manage human activities in deltas. Day et al. have elaborated a hierarchical model of deltaic sustainability as a function of geomorphic, ecological, and economic sustainability. This can be used to assess the effectiveness of various decision making scenarios, including methods of numerical modeling such as used by Sampath and Boski for future projection of morphological evolution of the Guadiana Estuary. Thus, scientists are providing assessment tools to support sustainability, but this can only be successful if the 
various stakeholders decide to cooperate and implement management measures.

Indeed this is also the approach described by Nicholls et al. for managing the Ganges-Brahmaputra-Meghna delta in Bangladesh, where the ecosystem services provided by the delta support the livelihoods for the poorest communities. The management question is how to develop the delta in a sustainable way that benefits all residents. Nicholls et al. present an integrated framework to analyse changing ecosystem services in deltas and the implications for human well-being, focussing in particular on the provisioning ecosystem services of agriculture, inland and offshore capture fisheries, aquaculture and mangroves that directly support livelihoods. Their analysis is used to explore biophysical and social outcomes for the delta under different policy choices.

For sustainable conservation and restoration of coastal zones and rivers mouths we have to develop a holistic view to these systems' functioning. We have to learn to understand coasts as compartments of a complex source-to-sink chain of particulate and dissolved matter from the terrestrial drainage areas to the final marine depo-centers. Kemp et al. describe this approach in their paper about the Mississippi River delta. They detail how the decreasing load of sediment delivered to the delta corresponds directly to damming actions upstream the Mississippi and Missouri rivers, and to river diversion within the delta. This impact is exacerbated within the river mouth by dredging for raw material and for deepening navigational channels. The Mississippi River delta stands as an example for most of the big rivers worldwide that suffer from a decrease in the amount of sediment (Milliman and Farnsworth, 2013; see Chu et al., 2009 for the major Chinese rivers), which prevents and even reverses the natural evolution of deltaic river mouth systems, wetlands and marshes. Kemp et al. conclude that, to stop the destruction of the river delta, upstream river management is needed to shunt fine-grained sediments past as many as 50 dams in several U.S. states and this would be a massive effort requiring as much regional coordination and funding in this century as the monumental effort it took to build the dams. Day et al. in their paper propose an additional solution, namely the episodic large manmade diversions and crevasses $\left(>5000 \mathrm{~m}^{3} \mathrm{~s}^{-1}\right)$ that will result in rapid coastal restoration of up to $0.4 \mathrm{~m}$ in depth over areas up to $130-180 \mathrm{~km}^{2}$. Such an approach may find applications to threatened deltas worldwide.

Nhan demonstrates in his paper that increasing tidal flooding is occurring the Mekong River delta in Vietnam, which is starved of sediment by dams along the Mekong River, most of them being located in China. This flooding is exacerbated by land subsidence resulting from water and hydrocarbon exploitation, destruction of wetlands, and climatically controlled sea-level rise. He demonstrates that tidal flooding is exacerbated by changes of tidal dynamics in shallow coastal waters affected by sea level rise, i.e. the tides themselves are increased by the mean sea level rise.

The objective of coastal science for society is to support transformation to a future that is sustainable and resilient for both society and nature on the coast. The global and local challenge is to both identify and resolve unsustainable practices at the coast and in the catchment and to offer science-based solutions. These are lofty ideals and ambitious objectives; indeed beside wishful thinking, can science really affect the outcome?

Several papers in this issue also offer a glimmer of hope through three good-news case studies that such an outcome can be achieved. In the first good-news case study, in their paper about Chilika lagoon in India, Benthou et al. use the UNESCO estuarine ecohydrology model to quantify the degree to which the lagoon fisheries depend on land-use in the catchment, on the flushing through the inlet linking the lagoon with the sea, and on the local fisheries. They demonstrate that land-use in the catchment and the engineering structures stabilising the inlet, as well as the fisheries within the lagoon itself, must all be managed together in order for the fisheries to be sustainable. This approach is being implemented in practice by the Chilika Development Authority.

In the second good-news case study, Shelton and Richmond describe the community-based initiative in Guam, run by volunteers. To reduce erosion and ultimately help restore coral reefs, they planted trees and filter socks in eroding hillsides in the La Sa Fu'a River catchment above Fouha Bay. Based on the observed sediment trapping efficiency of these restoration efforts, Shelton and Richmond calculate that $0.05 \mathrm{~km}^{2}$ of severely eroding hillsides must be treated with $19 \mathrm{~km}$ of socks and 11,000 trees planted in order to trap 2121 tons of sediment in the river catchment to achieve the necessary reduction in sediment discharge to Fouha Bay. It is a huge undertaking but it is achievable because the community is interested and willing to commit. Once sediment input into the bay is controlled, existing sediment will clear out with stormdriven swell and the coral reefs should recover.

The third good-news story is from Japan, where major efforts have been carried out for the last thirty years to restore estuaries and bays under the concept of Sato-Umi (Yanagi, 2007, 2015). Matsuda and Kuboku describe the case study of Ago Bay in Shima City, Japan, where land-sea interaction at two sites was improved by promoting water exchange across dikes constructed for land development and land reclamation. The community is very much involved. Tidal flat restoration experiments conducted in Ago Bay clearly showed that the promotion of tidal exchange between the sea and wetland area on the inner side of dikes improved both deteriorated sediment quality and macro-benthos conditions.

There are limits to how much estuaries can be restored (Duarte et al., 2009, 2015; Elliott et al., 2016), but these three good-news case studies demonstrate that science-based restoration efforts can be successful in achieving some of the societal goals to live in a healthy, productive environment, with community involvement, (Newton and Elliott, 2016).

In order to halt and reverse the degradation to our coastalsocial-ecological systems we need first to define our aspiration for our future coasts. Next, we should define the coastal "boundaries" within the Earth System (Rockström et al., 2009a,b; Steffen et al., 2015), but not just from the bio-physical aspects. We must incorporate the human dimension, increasingly important in the Anthropocene; as the case studies in this Special Issue demonstrate, success depends on community involvement. We must explore the pathways that lead us back from the edge of the boundaries to the central space, where our coastal aspirations and sustainability will lie in the future.

\section{Acknowledgements}

The editors express their thanks to the Yantai Institute of Coastal Zone Research in China and to Professor Yongming Luo for encouragement and support. Alice Newton was supported by a Chinese Academy of Sciences scholarship.

\section{References}

Borja, A., Elliott, M., Snelgrove, P.V.R., Austen, M.C., Berg, T., Cochrane, S., Carstensen, J., Danovaro, R., Greenstreet, S., Heiskanen, A.-S., Lynam, C.P., Mea, M., Newton, A., Patrício, J., Uusitalo, L., Uyarra, M.C., Wilson, C., 2016. Bridging the gap between policy and science in assessing the health status of marine ecosystems. Front. Mar. Sci. 3, 175. http://dx.doi.org/10.3389 fmars.2016.00175.

Chu, Z.X.S.K., Zhai, S.K., Lu, X.X., Liu, J.P., Xu, J.X., Xu, K.H., 2009. A quantitative assessment of human impacts on decrease in sediment flux from major Chinese rivers entering the western Pacific Ocean. Geophys. Res. Lett. 36, 19. http:/ dx.doi.org/10.1029/2009GL039513.

Duarte, C.M., Conley, DJ., Carstensen, J., Sanchez-Camacho, M., 2009. Return to 
neverland: shifting baselines affect eutrophication restoration targets. Estuaries Coasts 32, 29-36.

Duarte, C.M., Borja, A., Carstensen, J., Elliott, M., Krause-Jensen, D., Marba, N., 2015. Paradigms in the recovery of estuarine and coastal ecosystems. Estuaries Coasts 38, 1202-1212.

Elliott, M., Mander, L., Mazik, K., Simenstad, C., Valesini, F., Whitfield, A. Wolanski, E., 2016. Ecoengineering with ecohydrology: successes and failures in estuarine restoration. Estuarine, Coast. Shelf Sci. 176, 12-35.

Milliman, J.D., Farnsworth, K.L., 2013. River Discharge to the Coastal Ocean - a Global Synthesis. Cambridge University Press, Cambridge, 382 pp.

Newton, A., Elliott, M., 2016. A typology of stakeholders and guidelines for engagement in transdisciplinary, participatory processes. Front. Mar. Sci. 3 http:// dx.doi.org/10.3389/fmars.2016.00230.

Ramesh, R., Chen, Z., Cummins, V., Day, J., D'Elia, C.D., Dennison, B., Forbes, D.L., Glaser, B., Glavovic, B., Kremer, H., Lange, M., Larsen, J.N., Le Tissier, M., Newton, A., Pelling, M., Purvaja, R., Wolanski, E., 2015. Land-ocean interactions in the coastal zone: past, present \& future. Anthropocene 12, 85-98. http://dx. doi.org/10.1016/j.ancene.2016.01.005.

Rockström, J., Steffen, W., Noone, J., Persson, Å., Chapin III, F.S., Lambin, E.F. Lenton, T.M., Scheffer, M., Folke, C., Schellnhuber, H., Nykvist, B., De Wit, C.A., Hughes, T., van der Leeuw, S., Rodhe, H., Sörlin, S., Snyder, P.K., Costanza, R., Svedin, U., Falkenmark, M., Karlberg, L., Corell, R.W., Fabry, V.J., Hansen, J., Walker, B., Liverman, D., Richardson, K., Crutzen, P., Foley, J., 2009a. Planetary boundaries: exploring the safe operating space for humanity. Ecol. Soc. 14 (2), 32 (online). http://www.ecologyandsociety.org/vol14/iss2/art32/.

Rockström, J., Steffen, W., Noone, J., Persson, A., Chapin III, F.S., Lambin, E.F., Lenton, T.M., Scheffer, M., Folke, C., Schellnhuber, H., Nykvist, B., De Wit, C.A., Hughes, T., van der Leeuw, S., Rodhe, H., Sörlin, S., Snyder, P.K., Costanza, R., Svedin, U., Falkenmark, M., Karlberg, L., Corell, R.W., Fabry, V.J., Hansen, J., Walker, B., Liverman, D., Richardson, K., Crutzen, P., Foley, J., 2009b. A safe operating space for humanity. Nature 461, 472-475. http://dx.doi.org/10.1038/ 461472a.

Steffen, W., Richardson, K., Rockström, J., Cornell, S.E., Fetzer, I., Bennett, E.M., Biggs, R., Carpenter, S.R., de Vries, W., de Wit, C.A., Folke, C., Gerten, D. Heinke, J., Mace, G.M., Persson, L.M., Ramanathan, V., Reyers, B., Sörlin, S., 2015. Planetary boundaries: guiding human development on a changing planet. Science 347 (6223), 1259855.

Van den Belt, M., Costanza, R., 2011. Ecological economics of estuaries and coasts. Treatise on Estuarine and Coastal Science 12. Elsevier, Amsterdam, 482 pp.
Wolanski, E., Elliott, M., 2015. Estuarine Ecohydrology. An Introduction. Elsevier, Amsterdam, 322 pp.

Yanagi, T., 2007. Sato-umi: a New Concept of Coastal Sea Management. Terra Scientific Publishing Company, Tokyo, $86 \mathrm{pp}$.

Yanagi, T., 2015. Eutrophication and Oligotrophication in Japanese Estuaries. Estuaries of the World. Springer, Dordrecht, $97 \mathrm{pp}$.

Alice Newton*

NILU-IMPEC, Box 100, 2027 Kjeller, Norway

CIMA, Gambelas Campus, University of Algarve, 8005-139 Faro,

Portugal

Jan Harff

University of Szczecin, Institute of Marine and Coastal Sciences, Ul. Mickiewicza 18, PL, 70-383 Szczecin, Poland

Zai-Jin You

School of Civil Engineering, Ludong University, Yantai 264025, China

Hua Zhang

Key Laboratory of Coastal Environmental Process and Ecology Remediation, Yantai Institute of Coastal Zone Research, Chinese Academy of Sciences, Yantai 264003, China

Eric Wolanski

TropWATER and College of Marine and Environmental Sciences, James Cook University, Townsville, QLD, 4811, Australia

* Corresponding author. E-mail address: anewton@ualg.pt (A. Newton). 